\title{
Histological and radiological changes in cranial bone in the presence of bone wax ${ }^{1}$
}

\author{
Alterações histológicas e radiológicas no osso craniano na presença de cera de osso
}

\author{
Cassio Eduardo Raposo-Amaral', Ana Beatriz Albino de Almeida ${ }^{\mathrm{II}}$, Gustavo Paschoal ${ }^{\mathrm{III}}$, Daniela Franco Bueno ${ }^{\mathrm{IV}}$, Luiz Carlos \\ Vulcanov, Maria Rita Passos-Bueno $^{\text {VI }}$, Nivaldo Alonso ${ }^{\mathrm{VII}}$ \\ ${ }^{1}$ Research performed at Department of Genetics and Evolution Biology, Institute of Biosciences, University of Sao Paulo (USP), Brazil. \\ ${ }^{\mathrm{I}} \mathrm{MD}$, Plastic Surgeon, Institute of Craniofacial and Plastic Surgery, Campinas-SP, Brazil. Main author, involved with technical procedures and manuscript \\ writing. \\ II $\mathrm{PhD}$, Biologist, Institute of Craniofacial and Plastic Surgery, Campinas-SP, Brazil. Helped with technical procedures and manuscript writing. \\ III Engineer, Centro de Tecnologia da Informação Renato Arsher, Campinas-SP, Brazil. Analysis and interpretation of data. \\ Iv $\mathrm{PhD}$, Dentist, Department of Genetics and Evolution Biology, Institute of Bioscience, USP, Sao Paulo, Brazil. Surgical procedures and manuscript \\ writing. \\ ${ }^{\vee} \mathrm{PhD}$, Full Professor, Veterinary Medicine, State University of Sao Paulo (UNESP), Botucatu-SP, Brazil. Acquisition of data and computerized tomography \\ examinations. \\ ${ }^{\text {VI }} \mathrm{PhD}$, Full Professor, Department of Genetics and Evolution Biology, Institute of Bioscience, USP, Sao Paulo, Brazil. Collection and processing of study \\ informations and supervised all phases of the study. \\ ${ }^{V I I} \mathrm{PhD}$, Associate Professor, Plastic Surgery Division, Department of Surgery, USP, Sao Paulo, Brazil. Responsible for conception and design of the study.
}

\begin{abstract}
Purpose: To quantify the amount of bone formation in the calvarial region of Wistar rats after craniotomy using bone wax as a haemostatic agent. Methods: Surgery to produce bilateral, symmetric, full-thickness cranial defects (area: $18 \mathrm{~mm}^{2}$ ) was performed in eight animals. The right side of the cranium remained open and the edges of the left side osseous defect was covered with bone wax. Calvaria were imaged immediately after surgery and 12 weeks postoperatively by computerized tomography. The areas of the bone defects were measured in three-dimensional images using Magics 13.0 (Materialise-Belgic, software CAD). Results: The average amount of bone formation on the left and right side respectively was $4.85 \mathrm{~mm}^{2}$ and $8.16 \mathrm{~mm}^{2}$. Statistically significant differences between the amount of bone formation on the left and right sides were seen. Conclusion: Bone wax significantly diminishes the rate of bone formation in calvarial defects in a rat model.
\end{abstract}

Key words: Waxes. Skull. Hemostatics. Osteogenesis. Rats.

\section{RESUMO}

Objetivo: Quantificar a formação óssea da região da calvaria de ratos Wistar submetidos à craniotomia com a utilização de cera de osso como agente hemostático. Métodos: Cirurgia para realizar um defeito ósseo craniano bilateral, simétrico (área: $18 \mathrm{~mm}^{2}$ ) e com espessura total foi realizado em oito animais. O lado direito do crânio permaneceu aberto e as extremidades do defeito ósseo do lado esquerdo foram recobertas com cera de osso. O crânio foi submetido à avaliação radiológica imediatamente após a cirurgia e 12 semanas após a cirurgia com a utilização de tomografia computadorizada. As áreas dos defeitos ósseos foram medidas através de imagens tridimensionais e utilizando o programa de computador Magics 13.0 (Materialise-Belgic, software CAD). Resultados: A quantidade média de formação óssea no lado esquerdo e direito foi respectivamente de $4.85 \mathrm{~mm}^{2}$ e $8.16 \mathrm{~mm}^{2}$. Diferença estatisticamente significante foi observada entre o lado direito e esquerdo. Conclusão: A cera de osso diminuiu significativamente a formação óssea nos defeitos ósseos em modelo animal.

Descritores: Ceras. Crânio. Hemostáticos. Osteogênese. Rats. 


\section{Introduction}

Bone wax is a sterile mixture of beeswax and isopropyl palmitate, a palm oil-based emollient, moisturizer, and thickening and anti-static agent. The chemical formula of bone wax is $\mathrm{CH}_{3}\left(\mathrm{CH}_{2}\right)_{14} \mathrm{COOCH}\left(\mathrm{CH}_{3}\right)_{2}$, and it is used to control massive bleeding in thoracic surgery, orthopedic surgery, neurosurgery, and craniofacial surgery ${ }^{1-3}$. Although very effective in the control of bleeding due to tamponade action, bone wax is not an absorbable substance and may lead to adverse clinical consequences. Loss of bone grafts and persistent clinical infections due to the lack of bacterial clearance in the affected area were described in clinical reports ${ }^{4,5}$.

The severity of histological reactions to bone wax varies from inflammatory and foreign body reactions to intense fibrous reactions. Although not extensively described, late infection is rare but can occur months or years after surgery.

Several experimental studies reported the negative impact of bone wax in the osteogenesis of osseous defects because of a combination of inhibitory osteoblastic activities and a physical barrier that may prevent bone union ${ }^{6,7}$, but none of the studies quantified the amount of bone formation using computerized tomography at long term postoperative period in an osseous defect and the presence of bone wax. Several types of osseous defects in the alveolar and cranial regions have been used to test engineering approaches to improve bone formation ${ }^{8-10}$. However, few of these defects were used to test substances used clinically and, in contrast, could negatively influence osteogenesis. The clinical consequences of some of those products should be considered in daily practice.

The objective of this study was to quantify the amount of bone formation after a long-term postoperative period in Wistar rats that underwent craniotomy using bone wax as a haemostatic agent. Additionally, we accessed the histological reaction to bone wax after surgery, aiming to identify late infection and/or foreign body reaction.

\section{Methods}

All experiments were performed in accordance with the guidelines set by the Standing Committee on Animal Research of the Institution. Adult male, 4-month-old Wistar rats weighing 350 to $500 \mathrm{~g}$ were housed individually in a temperature-, light-, and humidity-controlled environment. Animals were fed a standard diet preoperatively. Postoperatively, animals were fed a normal diet ad libitum.

\section{Surgical procedure}

Animals were anesthetized using an intraperitoneal injection $(0.3 \mathrm{~mL} / 100 \mathrm{~g}$ body weight $)$ of ketamine hydrochloride $(5 \%)$ combined with xylazine $(2 \%)$. Skin and underlying soft tissues, including the periosteum, were exposed to allow bone surgery. Surgery to produce bilateral, symmetric, full-thickness cranial defects (area: $18 \mathrm{~mm}^{2}$ ) was performed in eight animals (total of 16 defects in 8 animals). The defect was standardized using methylmethacrylate mold. The right side of the cranium remained open and was used as a control. The edges of the bone defect on the left side were filled with bone wax over the bony rim, simulating a clinical situation (Ethicon, Brazil). A drill with a micromotor under constant irrigation with sterile water was used to prevent death of bony cells due to thermal injury. The underlying dura mater was left injured. Skin was closed with 5-0 nylon. Absorbable sutures were not used to close the periosteum to avoid possible foreign body reactions.

\section{Histological preparation}

Samples of the cranial defects on the left and right sides were prepared for histological analyses of the animals killed at 12 weeks after surgery. The studied tissue samples were fixed in $10 \%$ formalin for 24 hours, decalcified in 5\% formic acid for 48 hours, and embedded in paraffin. Two transverse sections in three animals were performed at the center of the defect covered with wax, measuring $5 \mu \mathrm{m}$ thick, stained with hematoxylin and eosin, and examined by light microscopy. No signs of dehiscence were notice on the surgical wounds at the time of sacrifice. No macroscopic evidence of inflammation was noticed prior to sacrifice.

\section{Radiographic analyses}

Calvaria were imaged immediately after surgery and 12 weeks postoperatively by computerized tomography $(n=16$ osseous defects). Imaging was reconstructed as three-dimensional isosurfaces using in Vesalius biomedical software (DT3D-CTIBrazil). Each three-dimensional image was evaluated at a critical threshold toll, with the densest intensity interpreted as bone. The area of the bone defect was measured in three-dimensional images using Magics 13.0 (Materialise-Belgic, Software CAD) at 0 and 12 weeks.

\section{Percentage of bone formation}

The percentage of bone formation was calculated as the difference between the initial area of bone defect from the area of the bone defect 12 weeks after surgery $\times 100$, with the product then divided by the original defect area $\left(18 \mathrm{~mm}^{2}\right)$. The deficit of bone formation caused by the bone wax was calculated as the difference of bone formation in the control group and the bone wax group.

\section{Statistical analysis}

The sizes of the cranial defects on the left and right sides as well as the amount of bone formation were compared using a paired $t$-test. All data were expressed as the mean \pm SEM. A value of $p<0.05$ was considered statistically significant. All analyses were performed using SPSS Software release 10.0 (SPSS, Inc., Chicago, IL).

\section{Results}

The average area of the left side cranial defect was 13.15 $\pm 3.14 \mathrm{~mm}^{2}$, and the average area of the right side cranial defect was $9.84 \pm 2.66 \mathrm{~mm}^{2}$. The average amount of bone formation of the left side was $4.85 \pm 3.14 \mathrm{~mm}^{2}$, and the average amount of bone 
formation of the right side was $8.16 \pm 2.66 \mathrm{~mm}^{2}$. Approximately one-third $(26.9 \%)$ of the calvarial bone defects in the bone wax group were filled by bone, whereas $45.3 \%$ of the defects in the control group were healed (Figures 1 and 2).
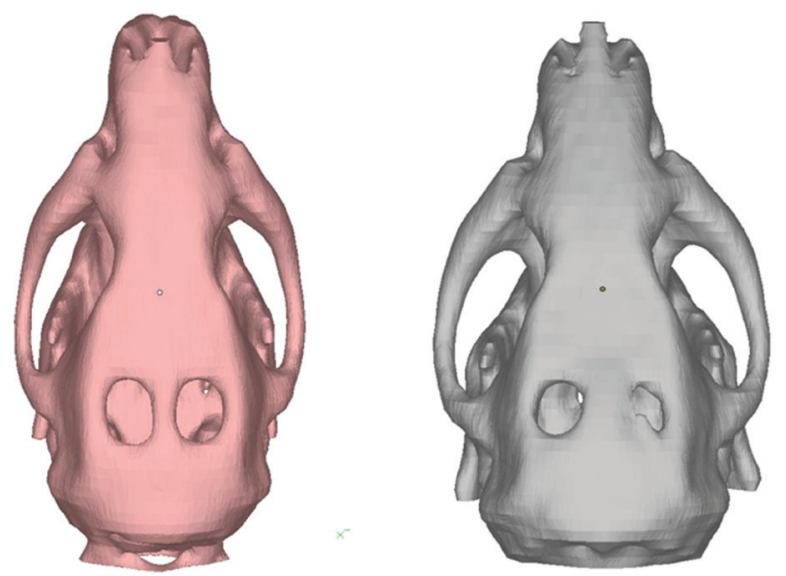

FIGURE 1 - Reformatted computed tomography image showing the initial size of cranial defects on the left and right sides, measuring $18 \mathrm{~mm}^{2}, 1$ day after surgery (Left). Reformatted computed tomography image 12 weeks after surgery, showing significant impairment of osteogenesis on the left side where bone wax was placed in the same animal. The right cranial defect had a higher rate of bone formation (control side) (Right).

\section{Mean area of bone formation $\left(\mathrm{mm}^{2}\right)$}

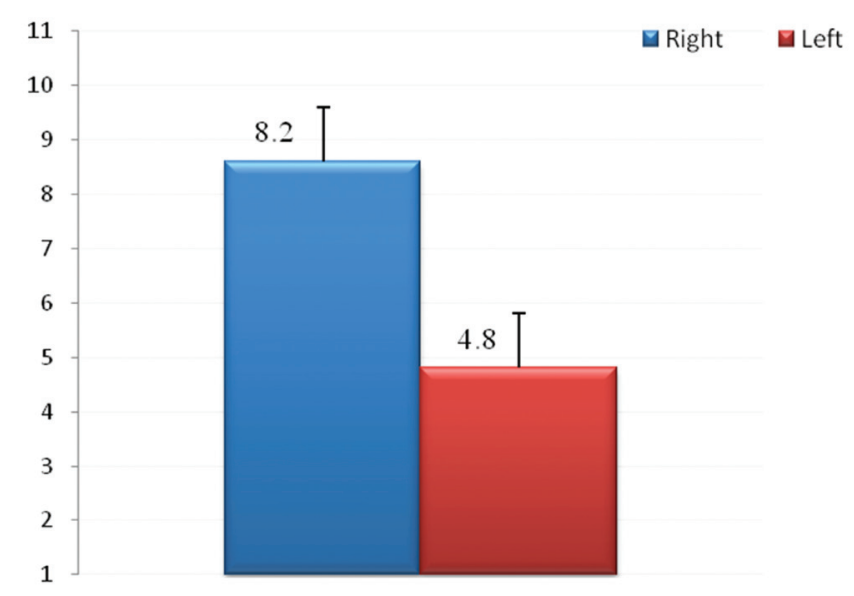

FIGURE 2 - Graph showing the mean \pm SEM area of new bone formation within the defects 12 weeks after surgery. The control group healed $45.3 \%$, whereas the bone wax group healed $26.9 \% 12$ weeks after surgery. An average $18.5 \%$ deficit in bone formation was caused by the bone wax.

Statistically significant differences between the amount of bone formation on the left and right (control) sides were seen $(p=0.01)$, with an approximate $18.5 \%$ deficit in bone formation on the bone wax side (left) compared with the controls.

\section{Histology}

Overall, several histological findings were observed 12 weeks after surgery in three histological slides, including a nonspecific inflammatory response, foreign body reaction, marked fibrous tissue reaction, and infection. Young fibrous connective tissue and accumulation of lymphocytes and neutrophils were seen 12 weeks after surgery. Additionally, a small number of macrophages were also noticed at this time. At a higher magnification $(\times 400)$, a neutrophilic exudate surrounded by fibrin and vessels, suggesting a microabscess formation, was seen (Figure 3).

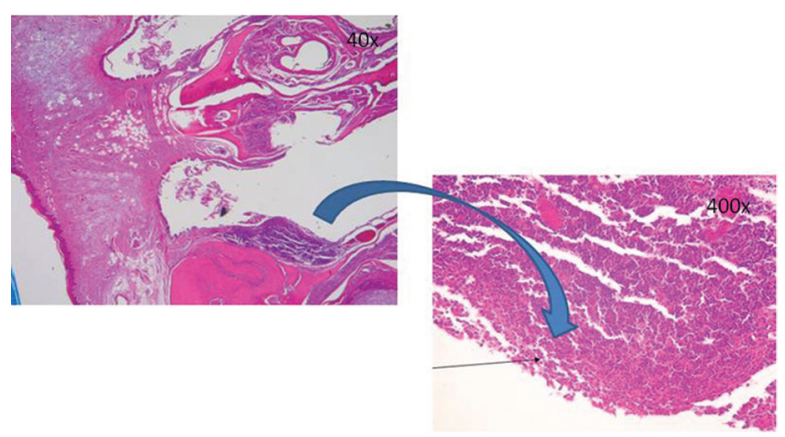

FIGURE 3 - Photomicrography of specimens after 12 weeks. Inflammation, lymphocytes, neutrophils, and small amounts of macrophages were seen in this slide. (Hematoxylin and eosin stain, original magnification 40×) (Left). At a higher magnification, a neutrophilic exudate forming a microabscess is evident (small black arrow). (Hematoxylin and eosin stain; original magnification, 400×) (Right).

Additionally, an abundant amount of fibrous tissue from a foreign body reaction was evident 12 weeks after surgery, lining the woven bone. There was also some local accumulation of multinucleated foreign body giant cells due to the presence of bone wax (Figures 4 and 5).

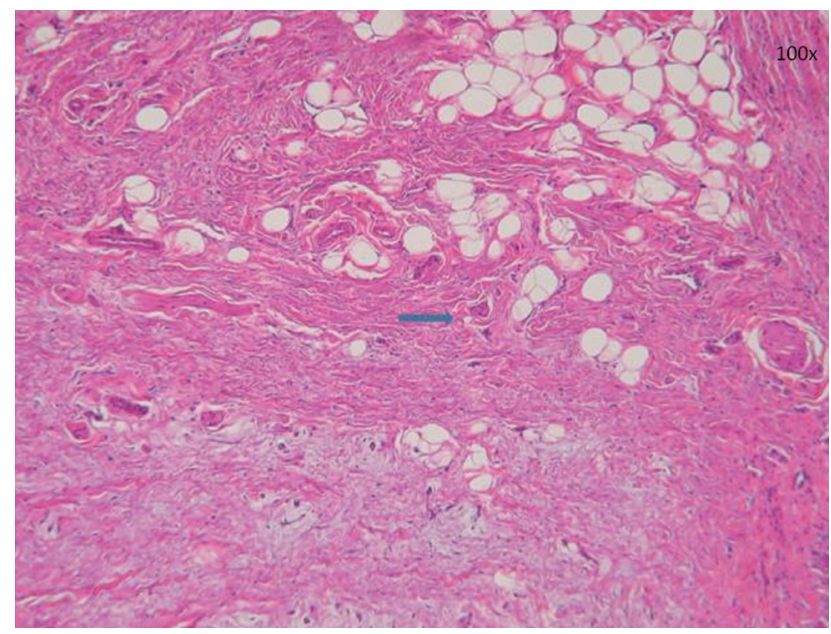

FIGURE 4 - Photomicrography of specimens after 12 weeks. Inflammation evidenced by an abundant amount of fibrous tissue from foreign body reaction is shown, lining the woven bone. There was some local accumulation of multinucleated foreign body giant cells due to the presence of bone wax (arrow). (Hematoxylin and eosin stain; original magnification, $100 \times)$. 


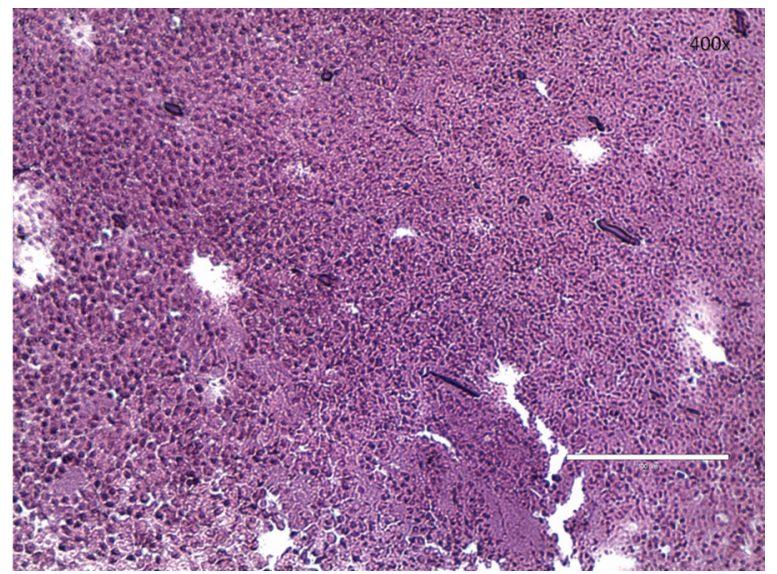

FIGURE 5 - Photomicrography of 12-week specimens. At a higher magnification, in a different area, a neutrophilic accumulation is shown (Hematoxylin and eosin stain, original magnification 400x).

\section{Discussion}

In our study, a variety of histological findings were seen 12 weeks after surgery. Some of these findings were not expected at a late follow-up period, such as intense inflammation and neutrophilic exudate, which are suggestive of abscess and infection. No signs of dehiscence were noticed on the surgical wounds at the time of sacrifice, and thus these findings may be caused by the presence of bone wax. Inflammation (as evidenced by the presence of polymorphonuclear leukocytes), was also seen 12 weeks after surgery. Additionally, a significant amount of fibrous connective tissue, the most expected sign of histological reaction at this time, was also seen in our study. Our findings suggest that even long after surgery, a variety of early signs of inflammation can occur and lead to undesirable clinical consequences. The multinucleated foreign body giant cells confirmed an immunologic response against the bone wax.

It is well known that bone wax has deleterious consequences in bone healing and may contribute to postoperative complications ${ }^{11-17}$. However, bone wax has been used in craniofacial surgery because of its efficiency and low cost.

Several experimental studies have shown the potential of bone wax to impair osteogenesis ${ }^{7,18}$, demonstrating impaired bone regeneration for tibial defects and cranial bone lesions ${ }^{7}$. There is a debate whether bone wax completely inhibits osteogenesis or simply diminishes the rate of bone formation, implying that bone wax could potentially block osteoblastic activities or serve as a mechanical barrier, interrupting its growth. In our study, bone formation in the cranial defect covered with wax occurred at a slower rate than the control, which implies that the amount of bone wax used in this experiment was insufficient to block osteoblastic activities, but sufficient to diminish the rate of bone formation. Thus, we hypothesize that bone wax causes a mechanical barrier to bone formation and does not inhibit osteoblastic activity. Several other variables may contribute to a delay in bone formation, such as injuries to the dura mater and periosteum, and thermal injuries caused by drilling holes with a high-speed drill, absence of irrigation, or use of a trephine ${ }^{19}$. To diminish any influence of thermal injuries and dura mater and periosteum lesions, the holes were drilled under constant irrigation and the use of trephine was avoided. The periosteum and dura mater were also carefully assessed immediately after craniotomy. Therefore, we suggest that none of these variables had an important impact on bone formation but that the deficit in bone formation was exclusively related to the action of the bone wax.

We assessed bone healing 12 weeks after surgery, considering that bone healing might plateau between 4 to 12 weeks after surgery. Additional healing over an 8-week time frame was described $^{20}$, and for that reason we sacrificed all animals after 12 weeks after surgery considering the potential healing between 8 -week and 12-week time frame.

No additional healing is expected at 12 weeks after surgery as previously showed ${ }^{10}$. We defined long-term evaluation as the longest period of postoperative care during which bone formation had stopped and no additional healing would be found. Thus, a 12-week time point was the optimal time to evaluate the clinical consequences and side effects of bone wax.

Czerwinski et al. ${ }^{21}$ reviewed morbidity and mortality rates during craniofacial surgeries and found an important correlation between mortality during major craniofacial procedures and significant blood loss during surgery: 50\% of mortality in major craniofacial procedures was attributed to blood loss. Thus, it is necessary to improve surgical methods to avoid serious complications. Recombinant erythropoietin, blood salvage with a "cell saver" device, routine use of electrocautery, and bone wax were all suggested to likely reduce overall blood loss and mortality rate ${ }^{22}$. However, even if bone wax significantly impairs osteogenesis, it might be beneficial by diminishing blood loss, and consequently, reducing morbidity and mortality rates. On the other hand, infection, potential loss of bone grafts, and impairment of osteogenesis in craniotomy sites might outweigh the benefits of bone wax.

\section{Conclusion}

Bone wax significantly diminished the rate of bone formation in a calvarial bone defect, leading to an approximate $18.5 \%$ deficit in bone healing and causing infection and fibrosis in an animal model 12 weeks after surgery.

\section{References}

1. Eser O, Cosar M, Aslan A, Sahin O. Bone wax as a cause of foreign body reaction after lumbar disc surgery: a case report. Adv Ther. 2007;24(3):594-7.

2. Katz SE, Rootman J. Adverse effects of bone wax in surgery of the orbit. Ophthal Plast Reconstr Surg. 1996;12(2):121-6.

3. Sudmann B, Bang G, Sudmann E. Histologically verified bone wax (beeswax) granuloma after median sternotomy in 17 of 18 autopsy cases. Pathology. 2006;38(2):138-41.

4. Johnson P, Fromm D. Effects of bone wax on bacterial clearance. Surgery. 1981;89(2):206-9.

5. Nelson DR, Buxton TB, Luu QN, Rissing JP. The promotional effect of bone wax on experimental Staphylococcus aureus osteomyelitis. J Thorac Cardiovasc Surg. 1990;99(6):977-80.

6. Papay FA, Morales L, Jr., Ahmed OF, Neth D, Reger S, Zins J. Comparison of ossification of demineralized bone, hydroxyapatite, Gelfoam, and bone wax in cranial defect repair. J Craniofac Surg. 
1996;7(5):347-51

7. Howard TC, Kelley RR. The effect of bone wax on the healing of experimental rat tibial lesions. Clin Orthop Relat Res. 1969;63:22632.

8. Costa Ade M, Kobayashi GS, Bueno DF, Martins MT, Ferreira Mde C, Passos-Bueno MR, Alonso N. An experimental model for the study of craniofacial deformities. Acta Cir Bras. 2009; 25(3):264-8.

9. Bueno DF, Kerkis I, Costa AM, Martins MT, Kobayashi GS, Zucconi E, Fanganiello RD, Salles FT, Almeida AB, do Amaral CE, Alonso N, Passos-Bueno MR. New source of muscle-derived stem cells with potential for alveolar bone reconstruction in cleft lip and/or palate patients. Tissue Eng Part A. 2009;15(2):427-35.

10. Nguyen PD, Lin CD, Allori AC, Ricci JL, Saadeh PB, Warren SM. Establishment of a critical-sized alveolar defect in the rat: a model for human gingivoperiosteoplasty. Plast Reconstr Surg. 2009;123(3):81725.

11. Aurelio J, Chenail B, Gerstein H. Foreign-body reaction to bone wax. Report of a case. Oral Surg Oral Med Oral Pathol. 1984;58(1):98-100.

12. Chun PK, Virmani R, Mason TE, Johnson F. Bone wax granuloma causing saphenous vein graft thrombosis. Am Heart J. 1988;115(6):1310-3.

13. Crocker M, Nesbitt A, Rich P, Bell B. Symptomatic venous sinus thrombosis following bone wax application to emissary veins. Br J Neurosurg. 2008;22(6):798-800.

14. Geary JR, Kneeland Frantz V. New absorbable hemostatic bone wax; experimental and clinical studies. Ann Surg. 1950;132(6):1128-37.
15. Gibbs L, Kakis A, Weinstein P, Conte JE, Jr. Bone wax as a risk factor for surgical-site infection following neurospinal surgery. Infect Control Hosp Epidemiol. 2004;25(4):346-8.

16. Julsrud ME. A surgical complication: allergic reaction to bone wax. J Foot Surg. 1980;19(3):152-4.

17. Ozdemir N, Gelal MF, Minoglu M, Celik L. Reactive changes of disc space and foreign body granuloma due to bone wax in lumbar spine. Neurol India. 2009;57(4):493-6.

18. Alberius P, Klinge B, Sjogren S. Effects of bone wax on rabbit cranial bone lesions. J Craniomaxillofac Surg. 1987;15(2):63-7.

19. Cooper GM, Mooney MP, Gosain AK, Campbell PG, Losee JE, Huard J. Testing the critical size in calvarial bone defects: revisiting the concept of a critical-size defect. Plast Reconstr Surg. 2010;125(6):1685-92.

20. Gosain AK, Song L, Yu P, Mehrara BJ, Maeda CY, Gold LI, Longaker MT. Osteogenesis in cranial defects: reassessment of the concept of critical size and the expression of TGF-beta isoforms. Plast Reconstr Surg. 2000;106(2):360-71; discussion 372.

21. Czerwinski M, Hopper RA, Gruss J, Fearon JA. Major morbidity and mortality rates in craniofacial surgery: an analysis of 8101 major procedures. Plast Reconstr Surg. 2010;126(1):181-6.

22. Fearon JA. Reducing allogenic blood transfusions during pediatric cranial vault surgical procedures: a prospective analysis of blood recycling. Plast Reconstr Surg. 2004;113(4):1126-30.

\section{Correspondence:}

Cassio Eduardo Raposo-Amaral

Hospital de Crânio e Face SOBRAPAR

Av. Adolpho Lutz, 100

Caixa Postal 6028

Campinas - SP Brasil

Tel: (55 19)3255-2520

Fax: (55 19)3254-7378

sobrapar@sobrapar.org.br
Conflict of interest: none

Financial source: FAPESP, CNPq, CEPID

Received: December 10, 2010

Review: February 14, 2011

Accepted: March 15, 2011 